\title{
Gimme Shelter: differential utilisation and propagule creation of invasive macrophytes by native caddisfly larvae
}

\author{
Kate Crane $\cdot$ Ross N. Cuthbert • Anthony Ricciardi • Louise Kregting • \\ Neil E. Coughlan $\cdot$ Hugh J. MacIsaac $\cdot$ Neil Reid · Jaimie T. A. Dick
}

Received: 27 February 2020/ Accepted: 26 August 2020/Published online: 4 September 2020

(C) The Author(s) 2020

\begin{abstract}
In aquatic systems, invasive submerged macrophytes considerably alter the structure and functioning of communities, thus potentially compromising ecosystem services. The prolific spread of invasive macrophytes is often aided by vegetative fragment propagation, yet the contributions of various commonly occurring invertebrates to such fragmentation are often unquantified. In the present study, we examine fragmentary spread of invasive macrophytes by a group of shredder-herbivores, larval caddisflies.
\end{abstract}

Kate Crane and Ross N. Cuthbert have contributed equally to this work.

Electronic supplementary material The online version of this article (https://doi.org/10.1007/s10530-020-02358-7) contains supplementary material, which is available to authorized users.

K. Crane $\cdot$ R. N. Cuthbert $(\square)$.

N. E. Coughlan · N. Reid · J. T. A. Dick

Institute for Global Food Security, School of Biological

Sciences, Queen's University Belfast, 19 Chlorine

Gardens, Belfast BT9 5DL, Northern Ireland, UK

e-mail: rossnoelcuthbert@gmail.com

K. Crane $\cdot$ R. N. Cuthbert $\cdot$ L. Kregting ·

N. E. Coughlan · N. Reid · J. T. A. Dick

Queen's University Marine Laboratory, 12-13 The Strand,

Portaferry BT22 1PF, Northern Ireland, UK

R. N. Cuthbert

GEOMAR Helmholtz-Zentrum für Ozeanforschung Kiel, 24105 Kiel, Germany
Through novel application of the comparative functional response (FR; resource use as a function of density) approach to the native case-building species Limnephilus lunatus, we compared utilisation of nonnative waterweeds Elodea canadensis and E. nuttallii in mono- and polycultures. Furthermore, we quantified de-cased and cased caddisfly-induced fragment production and length changes among non-native $E$. canadensis, E. nuttallii, Crassula helmsii and Lagarosiphon major under two different plant orientations: horizontal (floating) versus vertical (upright) growth forms. Larval caddisflies exhibited Type II (hyperbolic) FRs towards both Elodea species, and utilised each plant at similar rates when plants were provided separately. When plant species were presented in combination horizontally, E. canadensis was significantly less utilised compared to E. nuttallii,
A. Ricciardi
Redpath Museum, McGill University, 859 Sherbrooke
Street West, Montreal, QC H3A 0C4, Canada
L. Kregting
School of Natural and Built Environment, Queen's
University Belfast, Stranmillis Road, Belfast BT9 5AG,
Northern Ireland, UK
N. E. Coughlan
School of Biological, Earth and Environmental Sciences, University College Cork, Distillery Fields, North Mall,
Cork, Republic of Ireland 
corroborating observations in the field. De-cased larvae produced new plant fragments for all four aquatic macrophytes, whereas cased larvae fragmented plants significantly less. Elodea nuttalii and C. helmsii were fragmented the most overall. Crassula helmsii was utilised to the greatest extent when plants were horizontally orientated, and Elodea species when vertically orientated. This study identifies and quantifies a mechanism from a novel species group that may contribute to the spread of invasive macrophytes in aquatic systems. Whilst exploititative interactions are thought to impede invasion success, here we demonstrate how resource utilisation by a resident species may exacerbate propagule pressure from an invasive species.

Keywords Biodiversity conservation · Herbivory · Invasive species - Invertebrates · Macrophytes

\section{Introduction}

Freshwater ecosystems are increasingly invaded by alien species introduced accidentally or deliberately (Dudgeon et al. 2006; Ricciardi 2006; Seebens et al. 2017). Once established, alien species can impact biodiversity and alter key ecosystem functions such as productivity, nutrient cycling and hydrology (Dudgeon et al. 2006; Oreska and Aldridge 2011; Piria et al. 2017; Crane et al. 2020). For example, invasive macrophytes can form dense monotypic stands that alter physical habitat and biotic (vegetation, macroinvertebrates and fish) communities, as well as the interactions within and between these communities (Dibble et al. 1996). Invasive aquatic macrophytes are highly adaptable and competitive, and can, inter alia, grow rapidly, displace native plants and damage ecosystem services (BarratSegretain and Elger 2004; Redekop et al. 2016; Hussner et al. 2017; Szabó et al. 2018).

Many aquatic macrophytes reproduce asexually, propagating predominantly by vegetative rhizomes, turions or fragments (Barrat-Segretain 1996; BarratSegretain et al. 1998). Further, in response to abiotic factors such as wind, waves and water currents, human

H. J. MacIsaac

Great Lakes Institute for Environmental Research, University of Windsor, Windsor, ON N9B 3P4, Canada activities such as boating and fishing, as well as biotic factors such as herbivory, aquatic macrophytes are frequently broken into fragments. The fragments can disperse as propagules which later become new viable plants (Hussner 2009; Redekop et al. 2016; Coughlan et al. 2018). Production of macrophyte fragments by shredder-herbivores may be significant (Newman 1991; Pieczynska 2003; Maezo et al. 2010), and therefore when such consumers are present - particularly in high abundances - they could have serious implications for invasive macrophyte spread in terms of increasing propagule pressure (i.e. the number and frequency of individuals introduced to form an invader population; Lockwood et al. 2005). However, there is a distinct lack of quantitative data for utilisation or fragmentation rates of native/invasive aquatic macrophytes by shredder-herbivores (but see e.g. Carriera et al. 2014; Thouvenot et al. 2017).

Resource-use patterns of consumers can be quantified by measuring their functional response (FR), which describes the relationship between resource utilisation rate and resource availability (Solomon 1949; Holling 1959). Functional responses and associated resource preferences/switching have been identified as powerful tools to quantify invasive species impacts and invasion success (Dick et al. 2014; Cuthbert et al. 2018b; Skein et al. 2018), whereby Type II curves are thought to be resource destabilising due to high resource utilisation rates at low densities, whilst the converse is true for Type III FRs. However, whilst FRs are commonly applied to address consumer-resource interactions such as predation and herbivory (Dick et al. 2014; Xu et al. 2016a, b; Mu et al. 2018; Cuthbert et al. 2018a), there has hitherto been a lack of consideration for such per capita effects in shredder-herbivores, especially with regards to atypical resource utilisation behaviours, such as caddisfly case-building.

In consumer-resource (e.g. predator-prey) systems, invasion success is theoretically likely, and thus predictable, if invaders encounter lower biotic resistance compared to trophically analogous natives (see also the 'enemy release' hypothesis; Levine et al. 2004; Cuthbert et al. 2018b). Conversely, in the context of interactions involving invasive/native macrophytes, differential utilisation in favour of invaders may promote higher invasion success through greater propagation as a direct consequence of utilisation. Whilst stronger interactions towards 
invasive species over natives by grazers may contribute to biotic resistance (Oliveira et al. 2018), herbivore presence might enhance the fragmentation rate of invasive macrophytes that spread by vegetative propagules through direct and/or indirect effects (Thouvenot et al. 2019). For example, positive associations between invasive crayfish and macrophytes can result in reciprocal facilitations that heighten invasion dynamics (Thouvenot et al. 2017). Herbivore-plant interactions may also be mediated by plant traits, with characteristics such as nutritional properties, physical structure and secondary metabolites altering plant palatability (Hay 1996; Cronin et al. 2002; Elger and Lemoine 2005). In the case of resident herbivores, taxa that shred aquatic macrophytes (e.g. caddisfly larvae) may be important facilitative drivers of invasion via enhancing fragmentation and thus vegetative propagule pressure of aquatic plant species. Field observations of caddisfly larvae residing within swards of invasive Elodea species year-round have prompted us to assess the consumer-resource relationship and facilitated propagule creation.

Caddisflies (Trichoptera) are a group of insects that are widespread and abundant, and whose aquatic larvae comprise diverse functional feeding groups (Pescador et al. 1995; O'Connor 2015). Herbivorous case-building caddisfly larvae, such as Limnephilus spp., feed predominantly by shredding (Hanna 1959; Wiggins 2007), and are known to include submerged macrophytes in their diet (Jacobsen and Sand-Jensen 1994). The larvae of many caddisflies construct protective shelters (cases) using secreted silk to bind together particles that may include shells, mineral particles and plant parts (leaves and stems) (Gower 1967; Mouro et al. 2016). A new case is constructed at each larval instar stage, of which there are typically five during a life-cycle that spans up to 2 years, with case size increasing with each instar (Hanna 1959). Accordingly, dietary consumption coupled with case creation may drive high utilisation rates towards aquatic plants, year-round over an extensive larval life history. Given that the larvae recurrently create and augment cases across their larval life history, and feed on plant material, we hypothesise that they can play a significant role in fragmenting, and thus facilitating the spread of, invasive macrophytes that can disperse and establish vegetatively. The focal species, Limnephilus lunatus Curtis, is distributed widely throughout Europe and North America in both lenthic and lotic habitats, associated with plants, and forms an important component of aquatic food webs (Higler 1980).

In this study, we examine caddisfly usage of four non-native macrophytes that can reproduce vegetatively via fragments and, in many instances, have a detrimental impact on the receiving environment (see Table 1): Elodea canadensis Michx., Elodea nuttallii (Planch.) H. St. John, Crassula helmsii (Kirk) Cockayne and Lagarosiphon major (Ridl.) Moss. Elodea canadensis, Canadian waterweed, is a non-native submerged macrophyte that spread rapidly following its introduction to the United Kingdom (UK) in the early 1800s and is now naturalised in the UK and Ireland with relatively benign impacts (Newman and Duenas 2010). Elodea nuttallii. Nuttall's pondweed, is an invasive submerged macrophyte that can form dense monocultures that can displace E. canadensis and produce adverse ecological impacts (Simpson 1990; Barrat-Segretain 2001; Larson 2007). Crassula helmsii, New Zealand pigmyweed, is an invasive submerged, emergent or semi-terrestrial macrophyte, depending on the conditions into which it is introduced. It can form dense, monotypic stands, is extremely difficult to control (OEPP/EPPO 2007), and is considered a major invasive threat to the UK (Dawson and Warman 1987; Dawson 1994; Dawson and Leach 1999; Huckle 2002). Lagarosiphon major, African elodea, is a submerged macrophyte that grows in dense mats, is exceptionally difficult to control, and considered highly invasive (Caffrey et al. 2010, 2011). These plants were selected owing to their widespread establishment in the UK and Ireland, local availability and potential for coexistence in inland waters.

We used laboratory-based experiments to test the predictions that larval caddisflies of L. lunatus: (1) exhibit a preferential utilisation between the two Elodea species that may contribute to invasion success and replacement of E. canadensis by E. nuttallii; and (2) can cause increased fragmentation to a range of invasive macrophytes: E. canadensis, E. nuttallii, $C$. helmsii and L. major, and hence positively influence propagule pressure and invasion success. Here, for the first time, the FR concept is thus applied to a native herbivorous invertebrate-the caddisfly, L. lunatususing as a resource two alien macrophytes, $E$. canadensis and E. nuttallii. Furthermore, we quantify the capacity of this species to promote fragmentation in these and other macrophytes. 
Table 1 Study species, source site locations and invaded ranges of focal macrophtytes

\begin{tabular}{|c|c|c|c|c|}
\hline Species & Common name & Source site & Invaded range & Native range \\
\hline $\begin{array}{l}\text { Elodea canadensis } \\
\text { Michx. }\end{array}$ & $\begin{array}{l}\text { Canadian } \\
\text { waterweed }\end{array}$ & $\begin{array}{l}\text { Mill Pond } \\
\text { Tully Mill } \\
54^{\circ} 15^{\prime} 32.34^{\prime \prime} \mathrm{N} 7^{\circ} \\
42^{\prime} 50.88^{\prime \prime} \mathrm{W}\end{array}$ & $\begin{array}{l}\text { South America, Europe, Africa, Asia, } \\
\text { Oceania, invasive in native range }\end{array}$ & North America \\
\hline $\begin{array}{l}\text { Elodea nuttallii } \\
\text { (Planch.) H. St. John }\end{array}$ & $\begin{array}{l}\text { Nuttall's } \\
\text { waterweed }\end{array}$ & $\begin{array}{l}\text { Upper Lough Erne } \\
\text { Knockninny } \\
54^{\circ} 13^{\prime} 50.60^{\prime \prime} \mathrm{N} 7^{\circ} \\
34^{\prime} 14.20^{\prime \prime} \mathrm{W}\end{array}$ & Europe, Asia & North America \\
\hline $\begin{array}{l}\text { Crassula helmsii } \\
\text { (Kirk) Cockayne }\end{array}$ & $\begin{array}{l}\text { Australian } \\
\text { swamp } \\
\text { stonecrop }\end{array}$ & $\begin{array}{l}\text { Lough Beg } \\
54^{\circ} 47^{\prime} 28.60^{\prime \prime} \mathrm{N} 6^{\circ} \\
28^{\prime} 27.10^{\prime \prime} \mathrm{W}\end{array}$ & $\begin{array}{l}\text { Europe, North America, invasive in native } \\
\text { range }\end{array}$ & $\begin{array}{l}\text { Australia and } \\
\text { New Zealand }\end{array}$ \\
\hline $\begin{array}{l}\text { Lagarosiphon major } \\
\text { (Ridl.) Moss }\end{array}$ & African elodea & $\begin{array}{l}\text { Artificial Pond } \\
\text { Portadown Golf Club } \\
54^{\circ} 24^{\prime} 14.60^{\prime \prime} \mathrm{N} 6^{\circ} \\
24^{\prime} 51.30^{\prime \prime} \mathrm{W}\end{array}$ & $\begin{array}{l}\text { Europe, New Zealand, potentially invasive } \\
\text { in native range }\end{array}$ & Southern Africa \\
\hline
\end{tabular}

\section{Methods}

Organism collection and plant preparation

Elodea canadensis, E. nuttallii, $C$. helmsii and $L$. major were collected throughout Northern Ireland from a variety of lakes and ponds (Table 1). Pilot studies indicated that caddisfly larvae would actively utilise each species when provided singularly. Stems of each species were cut at the base, placed in coolers, and transported in source water to Queen's University Marine Laboratory, Portaferry, Northern Ireland. Prior to use, plants from each species were maintained in separate outdoor aquaria for approximately three months. Plants were then maintained within the laboratory at a constant temperature of $12 \pm 1{ }^{\circ} \mathrm{C}$ with aerated source water in $2 \mathrm{~L}$ arenas $(\mathrm{L} \times \mathrm{W} \times \mathrm{H}$ : $34 \times 34 \times 14 \mathrm{~cm})$. Larvae of $L$. lunatus were collected from Lough Erne (54 $12^{\prime} 02.9^{\prime \prime} \mathrm{N} 7^{\circ} 29^{\prime} 35.8^{\prime \prime}$ $\mathrm{W})$ by hand and identified as per Wallace et al. (2003). In Lough Erne, this species is associated with swards of both E. canadensis and E. nuttallii (K. Crane personal observation). Individuals were maintained in the same laboratory as the plants within aerated aquaria, filled with locally sourced lake water (Lough Cowey: 54 24' 41.79" N 5 32' 25.96" W) and Elodea spp. ad libitum, and starved for $48 \mathrm{~h}$ prior to experimentation. Case removal was carried out by widening the posterior opening using dissecting forceps, then gently pushing the caddis out using closed, rubber- tipped forceps. No caddisflies were found to be damaged through this process, and thus their ability to fragment plants was not impeded. Photon Flux Density was supplied by four $52 \mathrm{~W}$ Arcadia $1200 \mathrm{~mm}$ Marine Stretch LED lamps so that plants received $270 \mu \mathrm{mol} \mathrm{m} \mathrm{m}^{-2} \mathrm{~s}^{-1}$ under a $16 \mathrm{~h}$ light and $8 \mathrm{~h}$ darkness regime. The conditions aligned with those at the collection sites, and were relevant to the time of year when organisms were sampled. All plants were acclimated to the laboratory conditions for a $48 \mathrm{~h}$ period prior to experimentation in Lough Cowey water, during which all species exhibited excellent health and very little necrosis. All waste invasive plant material was destroyed by autoclaving.

Apical plant fragments were harvested $16 \mathrm{~h}$ prior to the start of each experiment and washed in dechlorinated tap water to remove any debris. Where possible, fragments were cut from unbranched sections of stem. However, if present, axillary side shoots were carefully removed. Fragments were briefly maintained $(<30 \mathrm{~min})$ in de-chlorinated tap-water immediately prior to being measured or weighed for experimental use (see next).

Experiment 1: Limnephilus lunatus case-building functional responses

Elodea canadensis and E. nuttallii fragments were randomly selected from holding aquaria (see before) and excess liquid was gently removed by manually 
spinning individual fragments, ten times in both directions, within a handheld centrifugal spinner. Individual apical fragments were cut to an exact fresh mass of either $100 \mathrm{mg}, 200 \mathrm{mg}, 300 \mathrm{mg}$ or $400 \mathrm{mg}$ (i.e. four different 'supply' treatment levels) (Mettler Toledo AB104). To quantify FRs of caddisfly larvae, individuals were presented with increasing plant biomass (similar to increased prey numbers, see $\mathrm{Xu}$ et al. 2016a, b). Two plant fragments of either single(E. canadensis or E. nuttallii) or mixed-species (one fragment of the same mass from each species) were placed in each container $(800 \mathrm{ml}$ plastic containers, $\mathrm{L} \times \mathrm{W} \times \mathrm{H}: 170 \times 110 \times 60 \mathrm{~mm}$, with $400 \mathrm{ml}$ water from Lough Cowey) within the laboratory (conditions as before). Individual de-cased or cased fifth-instar L. lunatus larvae were weighed (mean \pm SE: de-cased, $0.14 \pm 0.03 \mathrm{~g}$; cased, $0.59 \pm 0.10 \mathrm{~g}$ ) and one added to each treatment to quantify usage by plant species and caddisfly larvae types (i.e. de-cased, cased). Preference for one plant species over the other was then recorded using comparative functional response analyses (see later). Controls consisted of three replicates of each plant combination and mass without L. lunatus. All experimental groups were replicated three times. The experiment lasted $48 \mathrm{~h}$, after which wet masses of the original two plant fronds, provided at the start of the experiment, were quantified as before (i.e. accounting for utilisation via both case creation and consumption). We thus considered "utlisation" broadly in functional response analyses, whereby biomass changes resulting from direct consumption and case creation were pooled. The before-after differences in plant masses were used in analysis as caddisfly larvae-free control plants did not exhibit mass changes. Where two strands of individual species were used, the mean mass of both was used as a data point, whilst the single mass of each species was used for mixed species treatments. We then determined the proportion of plant mass utilised relative to the initial fresh mass supplied. Caddisfly larvae were weighed (wet mass) before and after the experimental period.

Experiment 2: Limnephilus lunatus plant fragmentation

Plants were randomly selected from holding aquaria (see before) and four apical fragments were cut to a standard length of $60 \mathrm{~mm}$ (i.e. total length per replicate $240 \mathrm{~mm}$ ). Four fragments of a single species (wet mass \pm SE: E. canadensis, $791 \pm 35 \mathrm{mg}$; E. nuttallii, $574 \pm 25 \mathrm{mg}$; C. helmsii, $380 \pm 19 \mathrm{mg}$; $L$. major, $2268 \pm 151 \mathrm{mg}$ ) were placed in $800 \mathrm{ml}$ plastic containers with $400 \mathrm{ml}$ lake water as before. Plants were either placed horizontally in containers or vertically as a bunch, weighted together at the base. Orientation was varied to examine whether L. lunatus would more likely shred the plant when floating or sunk in mats, or upright whilst growing and rooted in the substrate. Where vertically presented, the base of each individual fragment of plant was protected using a small piece of cotton wool before being wrapped with a $60 \times 5 \mathrm{~mm}$ lead plant weight, to keep the base of the fragment at the bottom of the container and the apical section positioned vertically. Individual decased or cased fourth-instar L. lunatus larvae were weighed (mean $\pm \mathrm{SE}$ : de-cased, $0.11 \pm 0.04 \mathrm{~g}$; cased, $0.32 \pm 0.1 \mathrm{~g}$ ) and one added to each treatment. All experimental groups were replicated three times. Controls contained one replicate of each plant species in the absence of caddisfly larvae under both orientations. The experiment was run over $168 \mathrm{~h}$ (one week) to allow L. lunatus sufficient time to shred plants, construct new cases or supplement existing ones. After the experiment, new plant fragments were recorded and the lengths of the initial four fragments were measured in combination within each replicate (i.e. accounting for both fragmentation and consumption). Final differences in lengths were then considered against final lengths of caddisfly larvae-free controls within each replicate (i.e. for each species and orientation). Only stem fragmentation was recorded; the removal of leaves did not constitute a viable fragment, as there is no evidence that the focal macrophytes can propagate from leaves alone. Caddisfly larvae were weighed before and after the experimental period as before.

\section{Statistical analyses}

All statistical analyses were performed using R v3.5.1 (R Core Development Team 2018). In Experiment 1, plant utilisation (response variable: proportion of initial plant mass used) under single-species exposures was analysed with respect to 'plant species' (2 levels: E. canadensis; E. nuttallii), 'caddisfly larvae type' (2 levels: de-cased, cased) and 'plant supply' (4 levels: $100 \mathrm{mg}, 200 \mathrm{mg}, 300 \mathrm{mg}, 400 \mathrm{mg}$ ) using linear 
models (LMs). For mixed plant exposures, linear mixed models (LMMs) with a random effect structure to account for repeated measures of the two plant species within each experimental replicate at a single time points were used (Bates et al. 2015). Proportioned plant utilisation was arcsine square-root transformed prior to analyses to improve normality and variance homogeneity (tested using Shapiro-Wilks and Levene's tests, respectively). Similarly, differences in de-cased caddisfly masses (response variable: change in mass) were examined using LMs separately for both single and mixed exposures, according to plant species and supply, or supply alone, respectively. Cased caddisfly masses did not change after the experiment and thus were not considered.

In Experiment 1, owing to negligible utilisation by cased caddisfly larvae in specific groups, comparative FR modelling was only feasible for de-cased caddisfly treatments. The 'frair' package in $\mathrm{R}$ (Pritchard et al. 2017) was used to analyse de-cased larval caddisfly FRs using maximum likelihood estimation (Bolker 2010) and the Lambert $W$ function (Bolker 2008). For each plant species separately, we deciphered FR types through logistic regression of the proportion of plant utilised (response variable: fragment mass change relative to original mass) as a function of the original mass supplied (continuous predictor). Here, Type II FRs were defined through a significantly negative linear coefficient (Juliano 2001).

We fit Rogers' random predator equation to account for non-replacement of plant material by the experimenter (Rogers 1972):

$N_{e}=N_{0}\left(1-\exp \left(a\left(h N_{e}-T\right)\right)\right)$

where $N_{e}$ is the quantity of plant utilised, $N_{0}$ is the initial plant mass, $a$ is the attack (i.e. shredding) rate, $h$ is the handling time and $T$ is the total time available. In a herbivory context, handling times may be considered as the time taken to utilise the plant resource. Regardless, the present study does not consider the attack rate and handling time parameters mechanistically, but instead considers them for comparative purposes in a factorial experimental design (Alexander et al. 2012). The attack rate and handling time are both central parameters of FR curves, with the attack rate corresponding to the original slope (i.e. search coefficient) and handling time corresponding to the asymptote (i.e. maximum feeding rate). Indicator variables were used to compare FR parameters between $E$. canadensis and $E$. nuttallii within single and mixed groupings (Juliano 2001). This approach compares FR parameters between groups via substitution of the $a / h$ estimate from Eq. 1 plus a coded predictor for the focal variable (see Paton et al. 2019). We used a non-parametric bootstrapping procedure ( $n=2000$ iterations) to generate $95 \%$ confidence intervals around FR curves.

In Experiment 2, raw counts of new fragments (response variable: number of new fragments) were analysed using negative binomial GLMs with $\log$ links. Fragment length changes relative to caddisfly larvae-free controls (response variable: fragment length change) of plants over the experimental period were analysed using LMs. For each of these models, 'plant species' (4 levels: E. canadensis, E. nuttallii, $C$. helmsii, L. major), 'plant orientation' (2 levels: horizontal, vertical) and 'caddisfly larvae type' (2 levels: de-cased, cased) were incorporated factorially. Yeo-Johnson transformations were used on plant length changes to homogenise variances and normalise residuals prior to analysis (Fox and Weisberg 2011). As before, de-cased caddisfly larvae masses were examined using LMs (response variable: change in mass) as a function of plant species and orientation, as cased caddisfly larve masses did not change over the experiment.

For all models, non-significant terms were removed stepwise to obtain the most parsimonious fit, and thus the final models included only significant terms. Tukey's comparisons were used for top model post hoc tests where terms were found to be significant at the $95 \%$ confidence interval via analysis of deviance. Effect sizes were derived through $F$-tests for LMs and LMMs and Chi square-tests for GLMs (Fox and Weisberg 2011). Owing to our sample size, the power to detect significance was low, and thus our results may be viewed as conservative in some instances.

\section{Results}

Experiment 1: Limnephilus lunatus case-building functional responses

In L. lunatus-free controls, $100 \%$ of the original mass of both Elodea species remained at the end of the experiment. Thus, experimental reductions in plant mass were deemed a result of utilisation by larval 
caddisflies, which was also evidenced by case creation/augmentation. In the final model, de-cased caddis utilised significantly more plant material than cased individuals, and utilisation was further mediated by plant supply. These terms also interacted, with utilisation rates decreasing with supply only in the case of de-cased caddis (Table 2a; Fig. 1a, b). Cased caddisly larvae always utilised significantly less than de-cased individuals (all $p<0.001$ ). We did not detect significance in differences between plant species or for other terms. Under mixed-species exposures (i.e. both plants together), however, significantly more $E$. nuttallii was utilised as compared to $E$. canadensis, whilst de-cased caddisfly larvae again utilised significantly more than cased equivalents (Table 2b; Fig. 1c, d). All other terms had no detected significance and were removed from the final model. De-cased caddisfly larvae masses did not change significantly between plants when presented singularly $\left(F_{1}, \quad 22=0.242, p=0.628\right)$, irrespective of supply $\left(F_{3,22}=0.445, p=0.724\right)$, with caddis gaining a mean of $52 \mathrm{mg}( \pm 7.5 \mathrm{SE})$ in mass over the experiment. Similarly, in the mixed treatments, caddisfly larvae masses did not change significantly across supplies $\left(F_{3,8}=2.018, p=0.190\right)$, with mean gains of $60 \mathrm{mg}$ ( $\pm 12.7 \mathrm{SE})$.

Type II case-building FRs were exhibited by decased caddisfly larvae towards both plant species, either when presented individually or simultaneously, owing to significantly negative linear coefficients (Table 3). When both E. canadensis and E. nuttallii were presented separately, we did not detect attack
Table 2 Model terms, degrees of freedom (df) and $p$ values for (a) linear models (LMs) on proportioned plant utilisation under singlespecies exposures as a function of plant species $(\mathrm{P}$, 2 levels), caddisfly larvae type (C, 2 levels) and plant supply (S, 4 levels); (b) linear mixed models (LMMs) on proportioned plant utilisation under mixed-species exposures as a function of plant species ( $\mathrm{P}, 2$ levels), caddisfly larvae type (C, 2 levels) and plant supply (S, 4 levels);

(c) GLMs on fragmentation counts as a function of plant species ( $\mathrm{P}, 4$ levels), plant orientation (O, 2 levels) and caddisfly larvae type (C, 2 levels); (d) LMs on fragment length changes as a function of plant species (P, 4 levels), plant orientation (O, 2 levels) and caddisfly larvae type (C, 2 levels)

Significant $p$ values are emboldened

\begin{tabular}{|c|c|c|c|}
\hline Model & Term & Effect coefficient (df) & $p$ value \\
\hline \multirow[t]{7}{*}{ (a) Utilisation (single species) } & $\mathrm{P}$ & $F(1)=0.051$ & 0.822 \\
\hline & C & $F(1)=142.53$ & $<0.001$ \\
\hline & $\mathbf{S}$ & $F(3)=5.602$ & 0.003 \\
\hline & $\mathrm{P}: \mathrm{C}$ & $F(1)=0.021$ & 0.887 \\
\hline & P:S & $F(3)=0.676$ & 0.573 \\
\hline & $\mathrm{C}: \mathrm{S}$ & $F(3)=2.971$ & 0.043 \\
\hline & $\mathrm{P}: \mathrm{C}: \mathrm{S}$ & $F(3)=0.574$ & 0.636 \\
\hline \multirow[t]{7}{*}{ (b) Utilisation (mixed species) } & $\mathbf{P}$ & $F(1)=26.358$ & $<0.001$ \\
\hline & C & $F(1)=70.250$ & $<0.001$ \\
\hline & $\mathrm{S}$ & $F(3)=0.665$ & 0.586 \\
\hline & $\mathrm{P}: \mathrm{C}$ & $F(1)=0.611$ & 0.446 \\
\hline & $\mathrm{P}: \mathrm{S}$ & $F(3)=0.189$ & 0.902 \\
\hline & $\mathrm{C}: \mathrm{S}$ & $F(3)=2.048$ & 0.148 \\
\hline & $\mathrm{P}: \mathrm{C}: \mathrm{S}$ & $F(3)=0.465$ & 0.711 \\
\hline \multirow[t]{7}{*}{ (c) Fragmentation } & $\mathbf{P}$ & $\chi^{2}(3)=14.039$ & 0.003 \\
\hline & $\mathrm{C}$ & $\chi^{2}(1)=3.773$ & 0.052 \\
\hline & $\mathrm{O}$ & $\chi^{2}(1)=1.191$ & 0.275 \\
\hline & $\mathrm{P}: \mathrm{C}$ & $\chi^{2}(3)=7.528$ & 0.057 \\
\hline & $\mathrm{P}: \mathrm{O}$ & $\chi^{2}(3)=0.353$ & 0.950 \\
\hline & $\mathrm{C}: \mathrm{O}$ & $\chi^{2}(1)=0.059$ & 0.808 \\
\hline & $\mathrm{P}: \mathrm{C}: \mathrm{O}$ & $\chi^{2}(3)=0.020$ & 0.999 \\
\hline \multirow[t]{7}{*}{ (d) Length change } & $\mathbf{P}$ & $F(3)=5.318$ & 0.004 \\
\hline & $\mathbf{C}$ & $F(1)=10.960$ & 0.002 \\
\hline & $\mathbf{O}$ & $F(1)=5.058$ & $\mathbf{0 . 0 3 2}$ \\
\hline & P:C & $F(3)=3.758$ & $\mathbf{0 . 0 2 0}$ \\
\hline & P:O & $F(3)=18.192$ & $<0.001$ \\
\hline & $\mathrm{C}: \mathrm{O}$ & $F(1)=1.146$ & 0.293 \\
\hline & P:C:O & $F(3)=4.414$ & 0.011 \\
\hline
\end{tabular}


Fig. 1 Mean ( \pm SE) proportion of fresh mass utilised of Elodea canadensis (Ec) and Elodea nuttallii (En) by de-cased (a, c) and cased (b, d) caddisfly larvae with plants presented in single (a, b) and in mixed (c, d) groups under different initial masses. Mass utilisation was calculated based on the difference between the starting and ending masses of initial fragments at each supply level
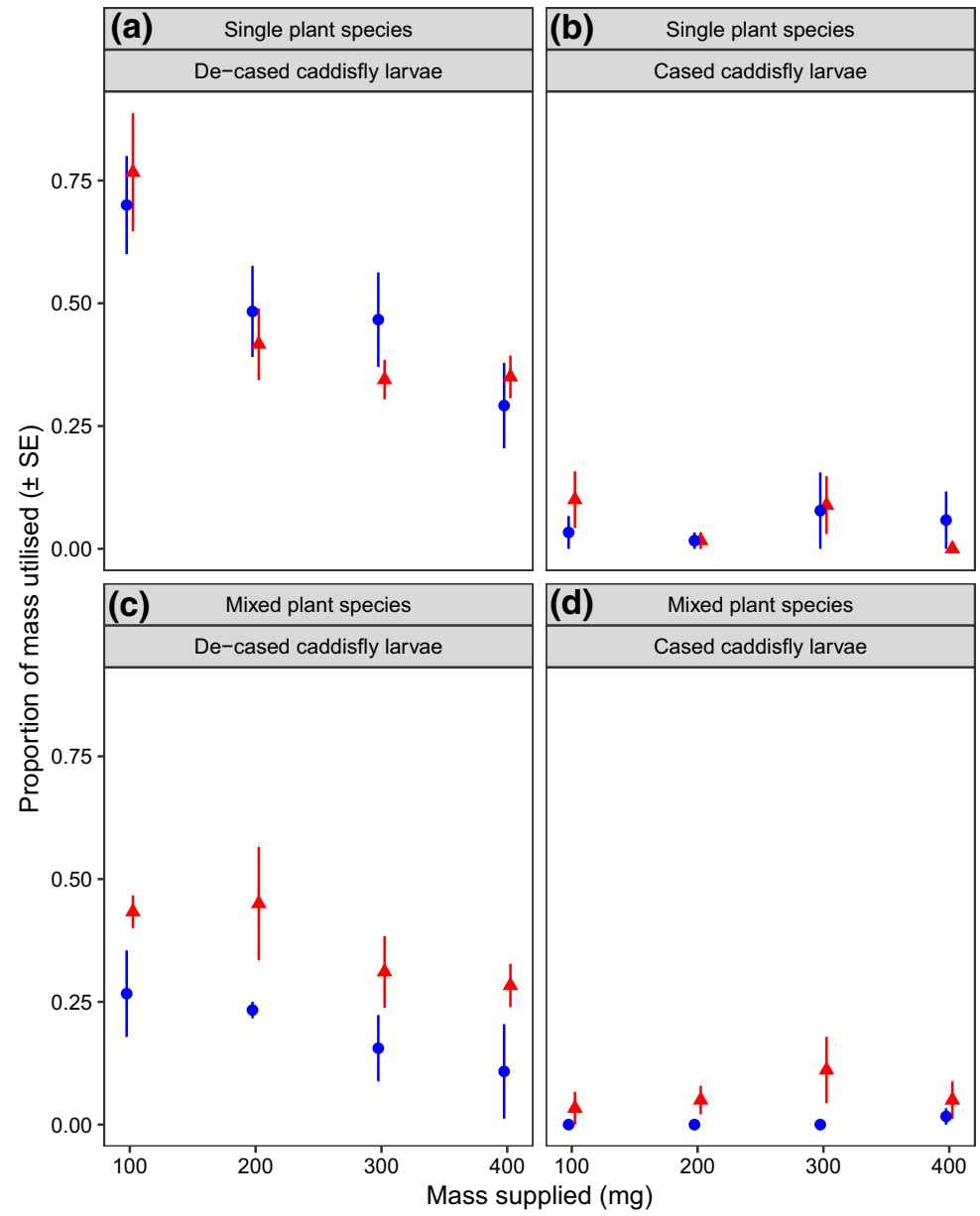

Plant species

$\rightarrow$ Ec

- En rates and handling times (and hence maximum utilisation rates) to differ significantly towards the two plants (attack rate, $z=0.862, p=0.389$; handling time, $z=1.712, p=0.087$ ). Accordingly, confidence intervals overlapped across all plant supplies (Fig. 2a). However, when both plants were presented together in mixed groups, attack rates differences were not detected $(z=0.897, p=0.370)$, whilst handling times

Table 3 Linear coefficient estimates and $p$ values resulting from logistic regression of the proportion of each plant species used as a function of original availability, alongside functional were significantly longer (and thus utilisation rates lower) towards $E$. canadensis compared to E. nuttallii ( $z=5.723, p<0.001)$. As such, L. lunatus exhibited a significantly greater FR magnitude towards $E$. nuttallii compared to E. canadensis in combined treatments, where FR confidence intervals did not overlap under the majority of intermediate-high plant masses supplied (Fig. 2b). Accordingly, caddisflies had a response parameter estimates. Significant $p$ values reflect confidence of differences from 0

\begin{tabular}{lllll}
\hline Species & Exposure & Linear coefficient, $p$ & Attack rate, $p$ & Handling time, $p$ \\
\hline E. canadensis & Single & $-0.005,<0.001$ & $2.116,<0.001$ & $0.006,<0.001$ \\
E. nuttallii & Single & $-0.004,<0.001$ & $2.565,<0.001$ & $0.007,<0.001$ \\
E. canadensis & Mixed & $-0.004,<0.001$ & $0.692,<0.001$ & $0.017,<0.001$ \\
E. nuttallii & Mixed & $-0.003,<0.001$ & $0.876,<0.001$ & $0.005,<0.001$ \\
\hline
\end{tabular}



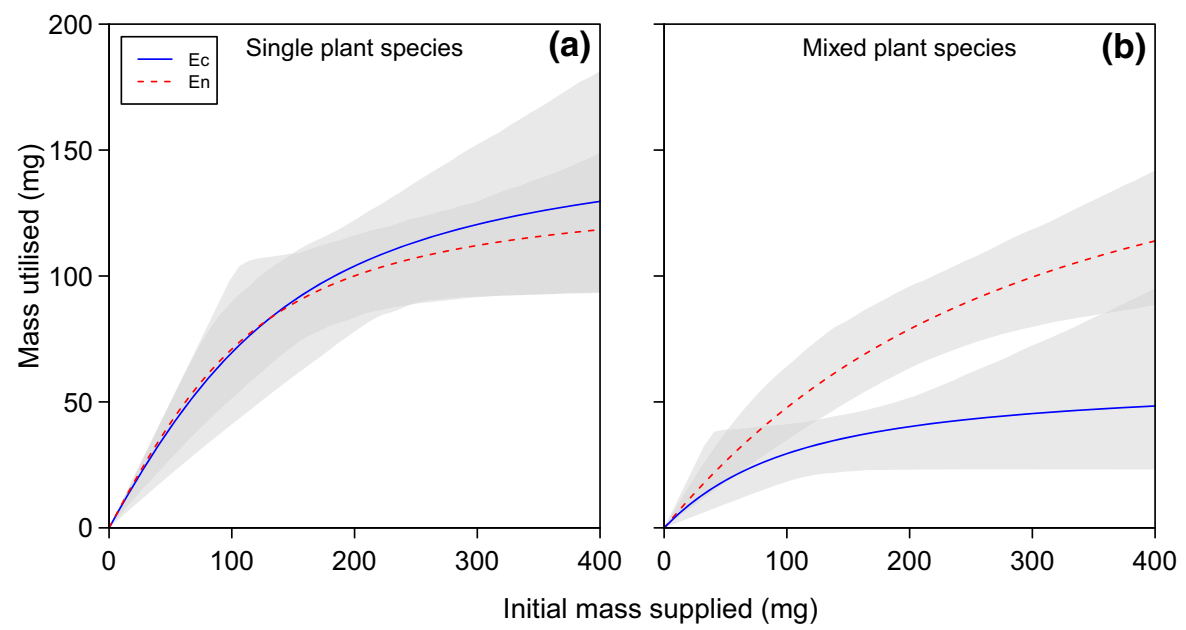

Fig. 2 Case-building functional responses of de-cased caddisfly larvae towards Elodea canadensis (Ec) and Elodea nuttallii (En) (fresh masses), with plants presented singly (a) or

selective preference towards E. nuttallii in mixed treatments.

\section{Experiment 2: Limnephilus lunatus plant} fragmentation

Limnephilus lunatus caused fragmentation of all four plant species, and thus created new propagules from the original fragments (Fig. 3a, b). On the other hand, no new fragments were created in caddisfly larvae-free controls. Plant species alone significantly influenced the quantity of fragments produced (Table 2c). In total, 19 fragments were created in the case of $C$. helmsii, whilst 6,5 and 3 were produced for $E$. nuttallii, E. canadensis and L. major, respectively. Overall, C. helmsii was significantly most susceptible to fragmentation (Fig. 3a, b). Cased caddis did not fragment E. canadensis or L. major, whilst de-cased caddis fragmented all plant species (Fig. 3a, b). Significance was not detected for all other terms and these were thus removed.

For total fragment length changes of the original fragments, a significant three-way interaction among plant species, orientation and caddisfly larvae was exhibited (Table 2d). As such, length changes were differentially mediated by orientation among plant species, depending on whether caddis were de-cased or cased (Fig. 4a, b). Specifically, for de-cased caddisfly larvae, macrophyte length differences between species were not statisticaly clear irrespective simultaneously in mixed groups (b). Shaded areas around curves represent bootstrapped $(n=2000) 95 \%$ confidence intervals

of plant orientation (all $p>0.05$ ). For cased caddisfly larvae, however, vertical $C$. helmsii grew significantly compared to all other plants (all $p<0.01$ ), that in turn generally exhibited similar length reductions following treatment (all $p>0.05$ ). Overall, regardless of orientation, E. nuttallii and C. helmsii trended towards greatest length reductions where caddisfly larvae were de-cased, whilst L. major were reduced most by cased caddisfly larvae (Fig. 4). De-cased caddisfly larvae mass gains did not change significantly according to plant orientation $\left(F_{1}, 20=0.947, p=0.343\right)$, yet differed according to plant treatment $\left(F_{1,20}=13.377, p<0.001\right)$, with larvae always significantly heavier following treatment with $L$. major (all $p<0.01$ ) (mean $\mathrm{mg} \pm \mathrm{SE}$ : L. major, $145.0 \pm 10.9 ;$ E. canadensis, $80.0 \pm 11.6$; E. nuttallii, $58.3 \pm 3.1 ;$ C. helmsii, $80.0 \pm 12.7$ ).

\section{Discussion}

Understanding mechanisms that allow introduced species to establish and spread is vital for management strategies and assessment of invasion risk (Flemming and Dibble 2015). For aquatic macrophytes, interactions with resident consumers may be a major determinant of invasion success. For example, Parker and Hay (2005) found that, in the receiving environment, native herbivores preferred non-native plants across taxonomic groupings that included crayfish 
Fig. 3 Mean ( \pm SE) number of new plant fragments of Elodea canadensis (Ec), Elodea nuttallii (En), Crassula helmsii $(\mathrm{Ch})$ and Lagarosiphon major (Lm) generated by de-cased (a) and cased (b) caddisfly larvae

Fig. 4 Mean ( \pm SE) fragment length changes of Elodea canadensis $(\mathrm{Ec})$, Elodea nuttallii (En), Crassula helmsii (Ch) and Lagarosiphon major (Lm) compared to controls following exposure to decased (a) and cased (b) caddisfly larvae. The dashed line represents zero change

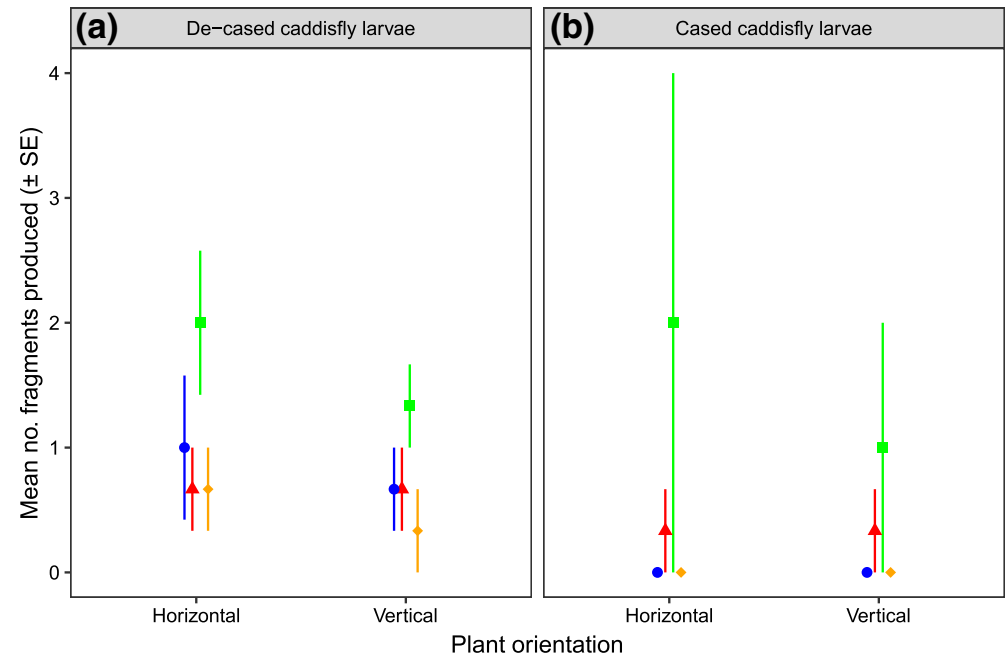

Plant species

$\rightarrow$ Ec

- En

$-\mathrm{Ch}$

$\rightarrow \mathrm{Lm}$

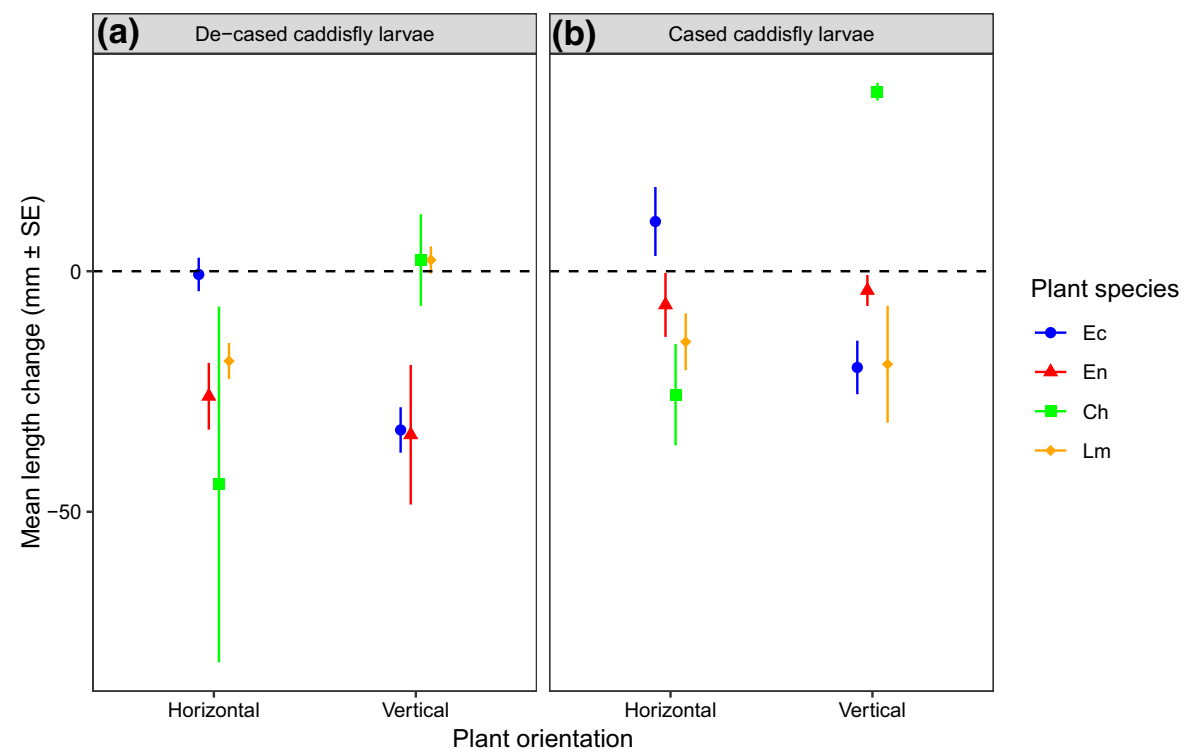

(Cambaridae), grasshoppers (Acrididae) and slugs (Ariolimacidae). Similar results have been shown in other study systems considering native herbivores (e.g. beavers [Castoridae], Parker et al. 2007; caterpillars [Crambidae], Redekop et al. 2018). However, the capacity of herbivore-shredders to enhance the invasiveness of alien macrophyte species through indirect effects has rarely been considered (Thouvenot et al. 2017, 2019).

The results of the FR experiment showed that there was little difference in utilisation where the non-native E. canadensis and high-impact invader E. nuttallii were presented individually. However, when offered simultaneously, L. lunatus preferentially used $E$. nuttallii over E. canadensis. Palatability has been shown to differ among Elodea species, and change seasonally by being higher during faster growth phases (Barrat-Segretain et al. 2002). Given that E. nuttallii allocates more resources to rapid growth than $E$. canadensis (Eugelink 1998), it may allocate fewer resources to deter herbivory (Barrat-Segretain et al. 2002). In turn, this may enhance invasion success by exacerbating fragmentation rates by herbivores. Resource use by cased L. lunatus larvae was low and, under most masses supplied, E. nuttallii was consistently selected whilst E. canadensis was never 
used. Nevertheless, de-cased caddis exhibited a Type II FR towards both plant species, under both single and mixed species groups. Therefore, proportional resource use by de-cased caddisfly larvae was high at low plant masses supplied, suggesting that these plants will be utilised by de-cased larvae at a high rate when relatively rare in aquatic environments. Accordingly, even when plant abundances are low, feeding caddisfly larvae could affect dispersal by fragmentation via utilisation of the plants. Increased production of plant propagules associated with caddis shredding could thus generate a higher rate of range expansion than the natural diffusion from a single large population alone (Hengeveld 1989). Therefore, we suggest that herbivorous caddisflies are not an effective natural enemy of these plants. Rather, in cases where plant dispersal is otherwise strongly limited, the relationship with caddisflies could be described as a mutualistic one. In our study system, consistent preferential utilisation could promote better spread of the high impact invader $E$. nuttallii over the relatively benign non-native E. canadensis. However, further research which examines additional combinations of macrophytes, as well as fragment viability and competition, is required to elucidate consumptive dynamics and preferences in freshwaters.

Where macrophyte species were presented singly, attack rates and handling times (and hence maximum utilisation rates) by de-cased L. lunatus were similar towards the two Elodea species. However, in mixed macrophyte combinations, whilst attack rates remained similar, handling times were significantly shorter and thus maximum utilisation rates higher, towards the invasive $E$. nuttallii. We consider these parameters comparatively rather than mechanistically, as they were not validated using empirical measurements (Alexander et al. 2012). The greater selective utilisation of E. nuttallii may be driven by the presence of longer, more malleable leaves, which could be easier to manipulate than the shorter, wider $E$. canadensis. Mechanistically, the implications of these results are not only that $L$. lunatus preferentially uses E. nuttallii, but that such shredders are also likely fragmenting it and enhancing its propagation. Displacement of E. canadensis by E. nuttallii can occur over a relatively short period of one to two years (Simpson 1990). As such, shredders that selectively fragment $E$. nuttallii could help drive or accelerate this shift in macrophyte community composition, yet also in combination with other factors such as plant resource use and growth rates.

Limnephilus lunatus larvae induced fragmentation in E. canadensis, E. nuttallii, C. helmsii and L. major, creating new propagules from the original fragments. Unsurprisingly, de-cased caddisflies produced substantially more fragments of all species than cased individuals owing to active case construction. Indeed, cased caddisflies never fragmented $E$. canadensis or $L$. major. Further, excepting C. helmsii, abilities of caddisfly larvae to fragment plants were mostly unaffected by the orientation of plants in our study. The majority of aquatic plants are capable of producing highly viable fragments, yet the minimum fragment size required for successful regeneration differs among species (Hussner 2009). Notably, many aquatic plant fragments, including some of those examined here, can regenerate from stem fragments comprising of a single node alone (Hussner 2009) and from sizes as small as $1-5 \mathrm{~cm}$ (Hussner 2009; Coughlan et al., 2018). Whilst new fragment sizes were not recorded in our study, it is likely that any new fragment produced which included at least one node could be viable. Future studies should thus consider both fragment size, and also the amount of nodes present both within and between species, for assessing regeneration likelihoods. In waterbodies, fragmentation instigated at the base of macrophyte swards by benthic-dwelling caddisfly larvae could release larger propagules in the form of long plant stems, e.g. 60-100 cm. Moreover, larval L. lunatus have been recorded in abundances as high as 160 individuals $\mathrm{m}^{-2}$ in freshwaters (Liess and Schulz 2009), and given that a new case is created for each of five instar stages, this could result in substantial propagule pressure should fragmentation occur, in addition to fragments created by consumption more generally. However, whether net population-level effects (i.e., via different consumer numerical responses or abundances) of herbivory by caddisfly larvae are facilitative or antagonistic for invasive macrophytes should be further examined in light of minimum viable propagule sizes and the sections of macrophyte swards that are preferentially grazed. In turn, whether multiple conspecific caddisfly larvae effects combine additively, antagonistically or synergistically in terms of fragmentation rates requires testing.

Successful management of invasive aquatic plants requires sound knowledge of their biology and, in this 
case specifically, their ability to regenerate following fragmentation. Since all of the examined macrophytes are spread by fragments, shredding could potentially have an impact on the spread of many invasive plants. Of the focal species, $C$. helmsii has exhibited a particularly high regeneration capacity and has the ability to form new shoots from single nodes (Hussner 2009). Bearing in mind this species was the most fragmented of all the examined macrophytes, coupled with its propensity to invade and become abundant, it especially appears to be facilitated by de-cased caddisfly larvae. Palatability in aquatic plants is linked to a range of traits including nutritional qualities, physical structure and secondary metabolites (Hay 1996; Cronin et al. 2002; Elger and Lemoine 2005). Zhang et al. (2019) found plant palatability to be negatively related to dry matter content, carbon:nutrient ratios and total phenolics, yet positively related to phosphorus and nitrogen levels in individual species. Moreover, herbivory has been found to positively relate to calcium and lignin contents (Bonar et al. 1990), however the extent which chemical properties influence plant selection by caddisfly larvae requires further investigation. As such, factors such as lignin content within and between plants, as well as physical deterrent effects, should also be considered in the context of caddisfly larval case creation. Shredders in aquatic systems may also be affected by seasonality (Boiché et al. 2010), which could reflect different in palatabilities owing to temperature variation. Moreover, in natural systems, fragmentation by caddisfly larvae of larger fronds may be coupled with hydrodynamics and influenced by stream size (Heidbüchel et al. 2019). Further work should consider these biotic and abiotic factors comparatively in order to better understand the drivers of differences in utilisation and fragmentation among key aquatic plants.

\section{Conclusion}

We have identified a potential mechanism that promotes the differential propagation of invasive macrophytes, depending on the plant-specific fragmentation properties. Larvae of $L$. lunatus showed a preference for invasive $E$. nuttallii over naturalised $E$. canadensis, and de-cased caddis fly larvae generated fragments from all of the examined macrophytes, but to different degrees. On the other hand, cased $L$. lunatus fragment macrophytes less between casebuilding episodes. Accordingly, large caddisfly larvae populations in freshwater systems infested with these macrophyte species might facilitate their further spread owing to their shredding activities. Our study identifies and quantifies a mechanism of propagule pressure from a novel group of species, by which resident herbivores potentially facilitate rather than limit invasion. The viability of the resulting propagules in the field remains to be determined.

Acknowledgements $\mathrm{KC}$ is supported through contributions from Queen's University Belfast, the University of Windsor, McGill University and Waterways Ireland. RNC is funded through a fellowship from the Alexander von Humboldt Foundation and acknowledges support from Department for the Economy (DfE), Northern Ireland. AR and HJM acknowledge support from NSERC Canada. NEC and JTAD are supported by the Irish EPA research grant 2015-NC-MS-4. We particularly thank Dr. Mary Kelly-Quinn for assistance with caddis species identification, Dr Elle O'Dea, Emma Healey and Maurice Collins for their helpful contributions. Thanks also to the Natural Environment Research Council (NERC).

Author contributions $\mathrm{KC}$ and $\mathrm{AR}$ proposed the study. $\mathrm{KC}$, RNC and NEC designed the experiments. KC conducted the experiments. RNC performed data analysis. All authors contributed considerably to writing the manuscript, which was led by RNC.

Funding Open Access funding provided by Projekt DEAL.

Data availability Underlying raw data will be made available in the online supporting information.

\section{Compliance with ethical standards}

Conflict of interest The authors declare no conflicts of interest.

Open Access This article is licensed under a Creative Commons Attribution 4.0 International License, which permits use, sharing, adaptation, distribution and reproduction in any medium or format, as long as you give appropriate credit to the original author(s) and the source, provide a link to the Creative Commons licence, and indicate if changes were made. The images or other third party material in this article are included in the article's Creative Commons licence, unless indicated otherwise in a credit line to the material. If material is not included in the article's Creative Commons licence and your intended use is not permitted by statutory regulation or exceeds the permitted use, you will need to obtain permission directly from the copyright holder. To view a copy of this licence, visit http://creativecommons.org/licenses/by/4.0/. 


\section{References}

Alexander ME, Dick JTA, O'Connor NE, Haddaway NR, Farnsworth KD (2012) Functional responses of the intertidal amphipod Echinogammarus marinus: effects of prey supply, model selection and habitat complexity. Mar Ecol Prog Ser 468:191-202

Barrat-Segretain MH (1996) Strategies of reproduction, dispersion, and competition in river plants: a review. Vegetatio 123:13-37

Barrat-Segretain MH (2001) Invasive species in the Rhône River floodplain (France): replacement of Elodea canadensis Michaux by E. nuttallii St. John in two former river channels. Archiv für Hydrobiologie 152:237-251

Barrat-Segretain M-H, Elger A (2004) Experiments on growth interactions between two invasive macrophyte species. J Veg Sci 15(1):109-114

Barrat-Segretain MH, Bornette G, Hering- Vilas-Bôas A (1998) Comparative abilities of vegetative regeneration among aquatic plants growing in disturbed habitats. Aquat Bot 60:201-211

Barrat-Segretain MH, Elger A, Sagnes P, Puijalon S (2002) Comparison of three life-history traits of invasive Elodea canadensis Michx. and Elodea nuttallii (Planch.) H. St. John. Aquatic Bot 74:299-313

Bates D, Maechler M, Bolker B, Walker S (2015) Fitting linear mixed-effects models using lme4. J Stat Softw 67:1-48

Boiché A, Gierlinski P, Thiébaut G (2010) Contrasting seasonal patterns in the acceptability of a naturalised and an introduced macrophyte for a generalist shredder. Fundam Appl Limnol 177:133-141

Bolker BM (2008) emdbook: ecological models and data in R. Princeton University Press, Princeton

Bolker, B.M. (2010). bbmle: tools for general maximum likelihood estimation. R Package

Bonar SA, Seghal HS, Pauley GB, Thomas GL (1990) Relationship between the chemical composition of aquatic macrophytes and their consumption by grass carp, Ctenopharyngodon Idella. J Fish Biol 36:149-157

Caffrey J, Millane M, Evers SL, Moran H, Butler M (2010) A novel approach to aquatic weed control and habitat restoration using biodegradable jute matting. Aquat Invasions 5:123-129

Caffrey J, Millane M, Evers S, Moran H (2011) Management of Lagarosiphon major (Ridley) moss in Lough Corrib-a review. Biol Environ Proc R Irish Acad 111:205-212

Carriera BM, Dias MP, Rebelo R (2014) How consumption and fragmentation of macrophytes by the invasive crayfish Procambarus clarkii shape the macrophyte communities of temporary ponds. Hydrobiologia 721:89-98

Coughlan NE, Cuthbert RN, Kelly TC, Jansen MAK (2018) Parched plants: survival and viability of invasive aquatic macrophytes following exposure to various desiccation regimes. Aquat Bot 150:9-15

Crane K, Coughlan NE, Cuthbert RN, Dick JTA, Kregting L, Ricciardi A, MacIsaac HJ, Reid N (2020) Friends of mine: an invasive freshwater mussel facilitates growth of invasive macrophytes and mediates their competitive interactions. Freshw Biol 65:1063-1072
Cronin G, Lodge DM, Hay ME, Miller M, Hill AM, Horvath T, Bolser RC, Lindquist N, Wahl M (2002) Crayfish feeding preferences for fresh water macrophytes: the influence of plant structure and chemistry. J Crustac Biol 22:708-718

Cuthbert RN, Dalu T, Wasserman RJ, Dick JTA, Mofu L, Callaghan A, Weyl OLF (2018a) Intermediate predator naïveté and sex-skewed vulnerability predict the impact of an invasive higher predator. Sci Rep 8:14282

Cuthbert RN, Dickey JWE, McMorrow C, Laverty C, Dick JTA (2018b) Resistance is futile: lack of predator switching and a preference for native prey predict the success of an invasive prey species. R Soc Open Sci 5:180339

Dawson FH (1994) Spread of Crassula helmsii in Britain. In: De Waal LC, Child LE, Wade PM, Brock JH (eds) Ecology and management of invasive riverside plants. Wiley, Chichester, pp 1-14

Dawson H, Leach J (1999) Crassula helmsii in the British Isles-an unwelcome invader. Br Wildl 10:234-239

Dawson FH, Warman EA (1987) Crassula helmsii (T. Kirk) Cockayne: is it an aggressive alien aquatic plant in Britain? Biol Cons 42:247-272

Dibble ED, Killgore KJ, Harrel SL (1996) Assessment of fishplant interactions. In: Miranda LE, Devries DR (eds) Multidimensional approaches to reservoir fisheries management. Am Fish Soc, Bethesda, pp 357-372

Dick JTA, Alexander ME, Jeschke JM, Ricciardi A, MacIsaac HJ, Robinson TB, Kumschick S, Weyl OLF, Dunn AM, Hatcher MJ, Paterson RA, Farnsworth KD, Richardson DM (2014) Advancing impact prediction and hypothesis testing in invasion ecology using a comparative functional response approach. Biol Invasions 16:735-753

Dudgeon D, Arthington AH, Gessner MO, Kawabata Z-I, Knowler DJ, Lévêque C, Naiman RJ, Prieur-Richard A-H, Soto D, Stiassny MLJ, Sullivan CA (2006) Freshwater biodiversity: importance, threats, status and conservation challenges. Biol Rev 81:163-182

Elger A, Lemoine D (2005) Determinants of macrophyte palatability to the pond snail Lymnaea stagnalis. Freshw Biol 50:86-95

Eugelink AH (1998) Phosphorus uptake and active growth of Elodea canadensis Michx. and Elodea nuttallii (Planch.) St. John. Water Sci Technol 37:59-65

Flemming JP, Dibble ED (2015) Ecological mechanisms of invasion success in aquatic macrophytes. Hydrobiologia 746:23-37

Fox J, Weisberg S (2011) An R companion to applied regression. SAGE Publications, Thousand Oaks

Gower AM (1967) A study of Limnephilus lunatus Curtis (Trichoptera: Limnephilidae) with reference to its life cycle in watercress beds. Trans Entomol Soc Lond 119:283-302

Hanna HM (1959) The growth of larvae and their cases and the life cycles of five species of caddis flies (Trichoptera). Proc R Entomol Soc Lond 34:121-129

Hay ME (1996) Marine chemical ecology: what's known and what's next? J Exp Mar Biol Ecol 200:103-134

Heidbüchel P, Sachs M, Stanik N, Hussner A (2019) Speciesspecific fragmentation rate and colonization potential partly explain the successful spread of aquatic plants in lowland streams. Hydrobiologia 843:107-123

Hengeveld R (1989) Dynamics of biological invasions. Chapman and Hall, London 
Higler LWG (1980) The presence of caddis flies in the Netherlands and their role in the aquatic system. Hydrobiol Bull 14:209-212

Holling CS (1959) Some characteristics of simple types of predation and parasitism. Can Entomol 91:385-398

Huckle J (2002) Invasive alien aquatic plant species, Crassula helmsii. Invasive Alien Species Project. Fact Sheet 1. English Nature \& University of Liverpool, Liverpool

Hussner A (2009) Growth and photosynthesis of four invasive aquatic plant species in Europe. Weed Res 49:506-515

Hussner A, Stiers I, Verhofstad MJJM, Bakker ES, Grutters BMC, Haury J, van Valkenburg JLCH, Brundu G, Newman J, Clayton JS, Anderson LWJ, Hofstra D (2017) Management and control methods of invasive alien freshwater aquatic plants: a review. Aquat Bot 136:112-137

Jacobsen D, Sand-Jensen K (1994) Invertebrate herbivory on the submerged macrophyte Potamogeton perfoliatus in a Danish stream. Freshw Biol 31:43-52

Juliano SA (2001) Nonlinear curve fitting: predation and functional response curves. In: Scheiner SM, Gurevitch J (eds) Design and analysis of ecological experiments. Oxford University Press, New York, pp 178-196

Larson D (2007) Non-indigenous freshwaters plants. Patterns, processes and risk evaluation. Swedish University of Agricultural Sciences, Uppsala

Levine JM, Adler PB, Yelenik SG (2004) A meta-analysis of biotic resistance to exotic plant invasions. Ecol Lett 7:975-989

Liess M, Schulz R (2009) Linking insecticide contamination and population response in an agricultural stream. Environ Toxicol Chem 18:1948-1955

Lockwood JL, Cassey P, Blackburn T (2005) The role of propagule pressure in explaining species invasions. Trends Ecol Evol 20:223-228

Maezo MJ, Fournier H, Beisner BE (2010) Potential and realized interactions between two aquatic invasive species: eurasian watermilfoil (Myriophyllum spicatum) and rusty crayfish (Orconectes rusticus). Can J Fish Aquat Sci 67:684-700

Mouro LD, Zatoń M, Fernandes CS, Waichel BL (2016) Larval cases of caddisfly (Insecta: Trichoptera) affinity in Early Permian marine environments of Gondwana. Sci Rep 6:19215

Mu X, Xu M, Ricciardi A, Dick JTA, Luo D, Wei H, Hu Y, Wei $Q$ (2018) The influence of warming on the biogeographic and phylogenetic dependence of herbivore-plant interactions. Ecol Evolut 9:2231-2241

Newman RM (1991) Herbivory and detrivory on freshwater macrophytes by invertebrates: a review. J North Am Benthol Soc 10:89-114

Newman JR, Duenas MA (2010) Information sheet 25: Elodea nuttallii, Nuttall's Pondweed. Information sheet 25: Centre for Ecology and Hydrology, Wallingford

O'Connor JP (2015) A catalogue and atlas of the Caddisflies (Trichoptera) of Ireland. Occasional Publication of the Irish Biogeographical Society, No. 11

OEPP/EPPO (2007) Crassula helmsii (Kirk) Cockayne. Data sheet on quarantine pests: Crassula helmsii (Kirk) Cockayne. Eur Mediterranean Plant Protect Organ Bull 37:225-229
Oliveira MV, Dainez M, Bertoncin AP, Muniz C, Meurer T, Figueiredo B, Thomaz SM, Fávaro SL, Mormul RP (2018) Native snails choose an invasive over a native macrophyte as a food resource. Can J Zool 97:362-367

Oreska MPJ, Aldridge DC (2011) Estimating the financial costs of freshwater invasive species in Great Britain: a standardised approach to invasive species costing. Biol Invasions 13:305-319

Parker JD, Hay ME (2005) Biotic resistance to plant invasions? Native herbivores prefer non-native plants. Ecol Lett 8:959-967

Parker JD, Caudill CC, Hay ME (2007) Beaver herbivory on aquatic plants. Oecologia 151:616-625

Paton RA, Gobin J, Rooke AC, Fox MG (2019) Population density contributes to the higher functional response of an invasive fish. Biol Invasions 21:1737-1749

Pescador ML, Rasmussen AK, Harris S (1995) Identification manual for the caddisfly (Trichoptera) larvae of Florida. Florida Department of Environmental Protection, Florida

Pieczynska E (2003) Effect of Damage by the snail Lymnaea stagnalis on the growth of Elodea canadensis. Aquat Bot 75:137-145

Piria M, Copp GH, Dick JTA, Duplić A, Groom Q, Jelić D, Lucy FE, Roy HE, Sarat E, Simonović P, Tomljanović T, Tricarico E, Weinlander M, Adámek Z, Bedolfe S, Coughlan NE, Davis E, Dobrzycka-Krahel A, Grgić Z, Kırankaya ŞG, Ekmekçi FG, Lajtner J, Lukas JAY, Koutsikos N, Mennen GJ, Mitić B, Pastorino P, Ruokonen TJ, Skóra ME, Smith ERC, Šprem N, Tarkan AS, Treer T, Vardakas L, Vehanen T, Vilizzi L, Zanella D, Caffrey JM (2017) Tackling invasive alien species in Europe II: threats and opportunities until 2020. Manag Biol Invasions 8:273-286

Pritchard DW, Paterson R, Bovy HC, Barrios-O'Neill D (2017) Frair: an $\mathrm{R}$ package for fitting and comparing consumer functional responses. Methods Ecol Evol 8:1528-1534

R Core Team (2018) R: A language and environment for statistical computing. R Foundation for Statistical Computing, Vienna

Redekop P, Hofstra D, Hussner A (2016) Elodea canadensis shows a higher dispersal capacity via fragmentation than Egeria densa and Lagarosiphon major. Aquat Bot 130:45-49

Redekop P, Gross EM, Nuttens A, Hofstra DE, Clayton JS, Hussner A (2018) Hygraula nitens, the only native aquatic caterpillar in New Zealand, prefers feeding on an alien submerged plant. Hydrobiologia 812:12-25

Ricciardi A (2006) Are modern biological invasions an unprecedented form of global change? Conserv Biol 21:329-336

Rogers D (1972) Random search and insect population models. J Animal Ecol 41(2):369-383

Seebens H, Blackburn TM, Dyer EE, Genovesi P, Hulme PE, Jeschke JM, Pagad S, Pyšek P, Winter M, Arianoutsou M, Bacher S, Blasius B, Brundu G, Capinha C, Celesti-Grapow L, Dawson W, Dullinger S, Fuentes N, Jäger H, Kartesz J, Kenis M, Kreft H, Kühn I, Lenzner B, Liebhold A, Mosena A, Moser D, Nishino M, Pearman D, Pergl J, Rabitsch W, Rojas-Sandoval J, Roques A, Rorke A, Rossinelli S, Roy HE, Scalera R, Schindler S, Štajerová K, Tokarska-Guzik B, van Kleunen M, Walker K, Weigelt P, 
Yamanaka T, Essl F (2017) No saturation in the accumulation of alien species worldwide. Nat Commun 8:1-9

Simpson DA (1990) Displacement of Elodea canadensis Michx by Elodea nuttallii (Planch.) H. St John in the British Isles. Watsonia 18:173-177

Skein L, Robinson TB, Alexander ME (2018) Impacts of mussel invasions on the prey preference of two native predators. Behav Ecol 29:353-359

Solomon ME (1949) The natural control of animal populations. J Anim Ecol 18:1-35

Szabó S, Peeters ETHM, Várbíró G, Borics G, Lukács BA (2018) Phenotypic plasticity as a clue for invasion success of the submerged aquatic plant Elodea nuttallii. Plant Biol 21:54-63

Thouvenot L, Haury J, Pottier G, Thiébaut G (2017) Reciprocal indirect facilitation between an invasive macrophyte and an invasive crayfish. Aquat Bot 139:1-7

Thouvenot L, Gauzens B, Haury J, Thiébaut G (2019) Response of macrophyte traits to herbivory and neighborings species: integration of the functional trait framework in the context of ecological invasions. Front Plant Sci 9:1981

Wallace ID, Wallace B, Philipson GN (2003) Keys to the casebearing caddis larvae of Britain and Ireland. Scientific
Publication of the Freshwater Biological Association, Ambleside

Wiggins GB (2007) Caddisflies: architects under water. Am Entomol 53:78-85

Xu M, Dick JTA, Ricciardi A, Fang M, Zhang C, Gu D, Mu X, Luo D, Wei H, Hu Y (2016a) Warming mediates the relationship between plant nutritional properties and herbivore functional responses. Ecol Evolut 6:8777-8784

Xu M, Mu X, Dick JTA, Fang M, Gu D, Luo D, Zhang J, Luo J, $\mathrm{Hu}$ Y (2016b) Comparative functional responses predict the invasiveness and ecological impacts of alien herbivorous snails. PLoS ONE 11:e0147017

Zhang P, Grutters BMC, van Leeuwen CHA, Xu J, Petruzzella A, van den Berg RF, Bakker ES (2019) Effects of rising temperature on the growth, stoichiometry, and palatability of aquatic plants. Front Plant Sci 9:1947

Publisher's Note Springer Nature remains neutral with regard to jurisdictional claims in published maps and institutional affiliations. 